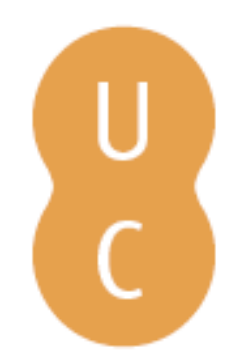

\title{
pommalina
}

\section{Ghosts stories in the Greek novel: a typology attempt}
Autor(es):
Ruiz Montero, Consuelo
Publicado por: Imprensa da Universidade de Coimbra
URL persistente:
URI:http://hdl.handle.net/10316.2/47487
DOI:
DOI:https://doi.org/10.14195/978-989-26-1765-7_1

Accessed : $\quad$ 26-Apr-2023 11:21:00

A navegação consulta e descarregamento dos títulos inseridos nas Bibliotecas Digitais UC Digitalis, UC Pombalina e UC Impactum, pressupõem a aceitação plena e sem reservas dos Termos e Condições de Uso destas Bibliotecas Digitais, disponíveis em https://digitalis.uc.pt/pt-pt/termos.

Conforme exposto nos referidos Termos e Condições de Uso, o descarregamento de títulos de acesso restrito requer uma licença válida de autorização devendo o utilizador aceder ao(s) documento(s) a partir de um endereço de IP da instituição detentora da supramencionada licença.

Ao utilizador é apenas permitido o descarregamento para uso pessoal, pelo que o emprego do(s) título(s) descarregado(s) para outro fim, designadamente comercial, carece de autorização do respetivo autor ou editor da obra.

Na medida em que todas as obras da UC Digitalis se encontram protegidas pelo Código do Direito de Autor e Direitos Conexos e demais legislação aplicável, toda a cópia, parcial ou total, deste documento, nos casos em que é legalmente admitida, deverá conter ou fazer-se acompanhar por este aviso.

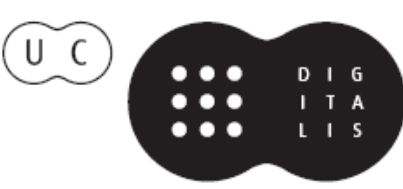




\section{Visitors from beyond the Grave}

\section{Ghosts in World Literature}

Dámaris Romero-González, Israel MuñozGallarte, Gabriel Laguna-Mariscal (eds.) 


\title{
Ghosts Stories in the Greek Novel: A Typology Attempt
}

\author{
Consuelo Ruiz Montero \\ University of Murcia \\ (orcid.org/0000-0001-8790-1896)
}

\begin{abstract}
Aвstract: This chapter offers a collection of texts belonging to ancient Greek novels dealing with ghosts, either in embedded tales or in episodes, both in extant complete novels and in papyri fragments. We will analyse nine texts and quote other parallels from both contemporary Greek and Latin literature. In our conclusions we will try to distinguish some of their types according to categories such as: tale enunciation, authentic and false ghosts, terminology, and physical description. Finally, we will remark on the rhetorical character of these stories.
\end{abstract}

KEYwORDs: Ancient Greek narrative, ghost, typology, rhetoric character.

It is well known that one of the typical features of the Imperial Age is the triumph of the irrational elements, as it is demonstrated by the faith in magic and all kinds of superstition and the rise of mystery religions. These features are well documented in magic papyri, inscriptions and literature. In the latter it should be noted that fiction permeates every literary genre of the period, and it manifests itself in genres such as paradoxography and novel, the genre of fiction par excellence, even though both genres have demonstrable interrelations. Thus, it seems interesting as well as relevant to explore the texts that deal with ghosts in the different types of Greek novel ${ }^{1}$. We will study both the stories and their diverse references to ghosts, and we will try to establish a typology, although it is a difficult task due to the fragmentary state of most of the texts we will analyse ${ }^{2}$.

1. Among the extant novels, the only complete story about the apparition of a ghost is found in Xenophon of Ephesus' Ephesiaca, a novel dated in the second

\footnotetext{
${ }^{1}$ For a diachronic outlook of this genre see Ruiz-Montero 2006, and, for an international volume about novel in the ancient world, see Schmeling 2003. For essential collections of papyri fragments of novels, see López Martínez 1998 and Stephens and Winkler 1995, with very few differences between the papyri quoted here. My texts follow those editions, although the translations are my own. The most recent volume edited by Bastianini and Casanova 2010 is also very useful, and there are occasional editions of later papyri, but not related to our topic. I also wish to thank the anonymous readers for their observations and the editors for their extraordinary kindness.

${ }^{2}$ In relation to this type of literature Stramaglia 1999 is essential, his collection of texts being accompanied by a profuse philological commentary, though he does not include any of the papyri commented on here. Ogden 2002: 146 classifies ghosts in four types: aôroi, "those who have died prematurely", bi(ai)othanatoi "those who have died violently", agamoi, "those who have died before their marriage", and ataphoi "those who were without funeral rites". These categories are not exclusive. On the topic see also Johnston 1999, who focuses on archaic and classical periods.
} 
century AD. Indeed, the heroine, Anthia, is forced to exhibit herself in a brothel, and in order to run from her situation, fakes an epileptic fit. She does this to preserve her chastity, following the compulsory standards of the Greek novels, which Xenophon takes to the highest paroxysm. Let us see the context of this story:

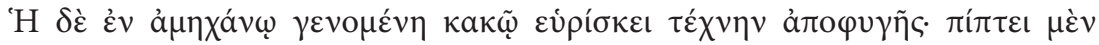

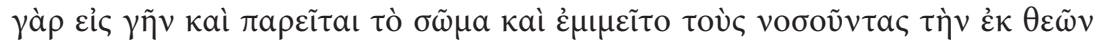

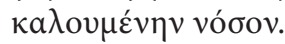

She, being in a desperate situation, finds a trick to escape: thus, she falls to the ground and relaxes her body, imitating those who suffer the illness called sacred (5. 7. 4).

Immediately afterwards, Anthia tells a fictitious story to the procurer:

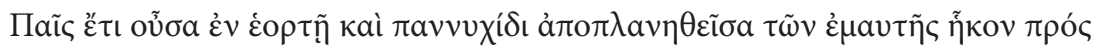

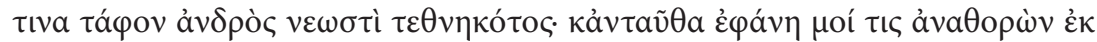

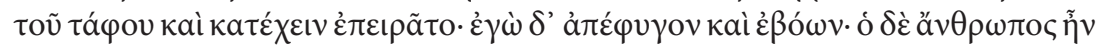

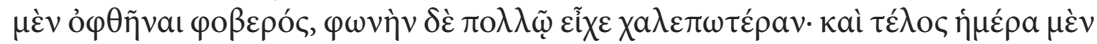

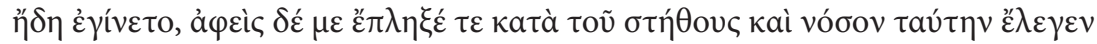

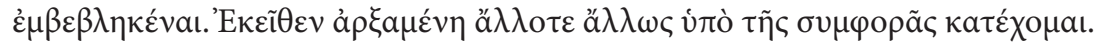

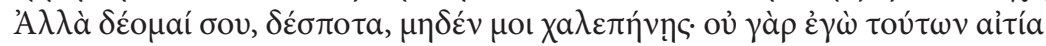

When I was still a little girl, I got away from my family during a night party and arrived to a certain grave of a recently dead man; and at that very moment someone, who was running out from the grave and tried to seize me, appeared to me. I took to flight and began to shout; the appearance of the man was horrible, and his voice was even more than terrible; and finally the dawn had already broken, and he released me after beating me in the chest, and he told me he had infected me with that illness. From that moment I am overcome by that illness in different ways. But I beg you, master, do not get angry with me, because I am not guilty of it (5. 7.7-9).

As it can be seen, Anthia pretends to suffer epilepsy in an aetiological narrative, which is an example of female cleverness of a folkloric nature. This type of episode is characteristic of the composition of this novel ${ }^{3}$. The story is

${ }^{3}$ For a study of this type of episode in Xenophon, see Ruiz-Montero 1998: 147. Plato (Phaed. 81d 2-3) has told already "ghosts, like shadows of souls, spectres like those who provide such

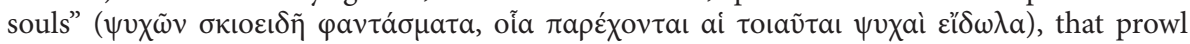
around the graves, and Athen. 9. 461c, concerning with the apparition of daimones, says that "they consider the heroes (are) cruel and violent, and even more at night than in the morning"

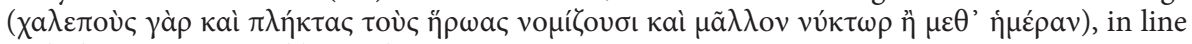
with the story narrated by Anthia. 
also proof of the general belief in this type of apparition. Otherwise, we do not know whether the ghost has run after Anthia or whether something more has happened during the night. It should be pointed out that the topic of the night party is very frequent in both New and Middle Comedy, in which many young girls are told to have been raped and became pregnant against their will. This is the plot of Phasma, that is, Ghost, by Menander, a play to which I will refer later ${ }^{4}$.

2. In Chariton's Callirhoe (probably written near the end of the first century $\mathrm{AD}$ ), we find another story about apparitions. The episode of the trial at Babylon deals with the decision about who the true husband of the heroine Callirhoe is, her first husband Chaereas, considered to be dead, or her new husband Dionysius. It is here where we find a scene in which Chaereas is apparently evoked. Mithridates, the Persian satrap, has prepared the scene, and the following occurs:

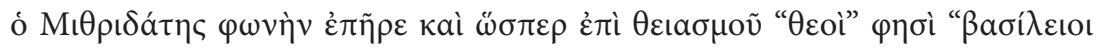

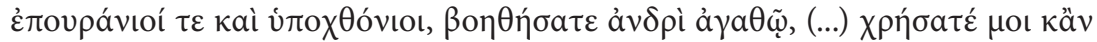

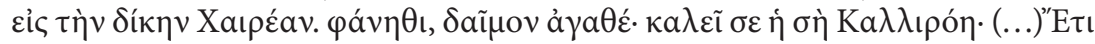

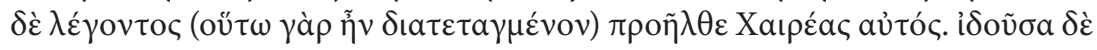

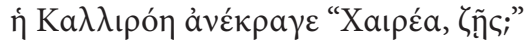

Mithridates raised his voice and, as being inspired by the divinity, said: "Heavenly and underground supreme gods, help a good man (...) lend me Chaereas, even if it is only for his trial. Appear, good spirit; your Callirhoe calls you"; (...) and while he was still speaking (because it was agreed to be so), Chaereas himself moved forward. When Callirhoe saw him, she cried out: "Chaereas, are you alive?" (5. 7. 10 - 8. 1).

The apparition of Chaereas' supposed ghost is part of the main plot. $\mathrm{He}$ is called a "good spirit", and he comes to see his wife out of love. The scene is presented and commented on by the author with words that fit dramatic plays very well: paradoxon mython (5. 8. 2) 5 . Keep in mind that in Greek literature ghosts appear since Il. 23. 65ff., where the ghost, here "soul" ( $p s y c h \bar{e})$, of Patro-

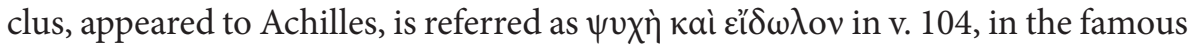
episode in Hades in Odyssey 116, and as daimones with the meaning of protective "spirits" are mentioned in Hes. Theog. 122 .

3. The Babyloniaca, by Iamblichus, is a novel whose plot we know thanks to Photius' abstract, Bib. cod. 94, according to which the novel can be dated

${ }^{4}$ About this play, see Barbieri 2001: 4-11, 123ff.

${ }^{5}$ In Charit. 5. 9. 4-5 Callirhoe asks herself whether Chaereas would not be an eidolon sent to the trial by Mithridates thanks to the Persian magic. Concerning this point, see the commentary by Plepelits 1976: 179 n. 125 .

${ }^{6}$ See Ogden 2002: 146-147. 
around $170 \mathrm{AD}$. This novel presents a scene in which the house of a killer and bandit is burnt by the soldiers of an evil king? In this case, the heroes, pursued by the king, elude the danger by pretending to be ghosts (This constitutes another example of cleverness, similar to that of Ephesiaca quoted before.) The text is as follows:

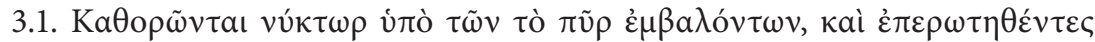

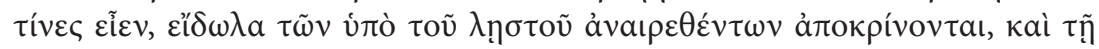

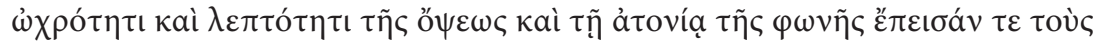

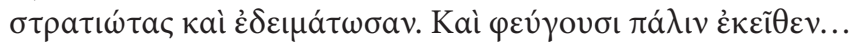

They are discovered at night by those who had thrown them in the fire, and when they were asked who they were, they answer "the ghosts of those murdered by the bandit", and because of their pale and skinny aspect and the weakness of their voices, they convinced the soldiers and terrorised them. And thus they escaped from there again... (74b37-42).

In this occasion the term used to name the ghosts is eidola, meaning "images" or "spectres".

The topic of the ghost is repeated in this novel, as it is demonstrated by a quote in the lexicon Suda (11th century AD) which explains the meaning of the term phasma:

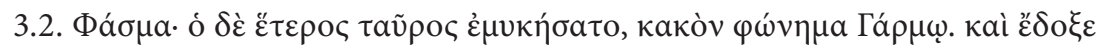

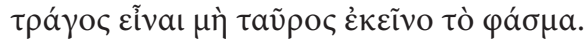

Phasma: "The other bull bellowed, a terrible sound for Garmus; and that ghost seemed to be a he-goat, not a bull" (4. 703. 20).

We know that Garmus is the evil king to whom we have referred to previously, and who plays the villain's role against the protagonists in the compositional structure of this novel. What we do not know is the context where the mentioned text is inserted, nor exactly to whom those ghostly bellows are referring to. Nevertheless, ghosts with animal shapes are also well documented in other Greek texts ${ }^{8}$.

Up to this point, we have examined novels narrated in the third person. Next, we will look at a papyrus that belongs to Antonius Diogenes' The incredible things beyond Thule. It is a novel that is narrated in the first person (according to the abstract kept by Photius, Bibl.cod. 166) and that has a chronology that

\footnotetext{
${ }^{7}$ For a study of fragments and testimonies I refer to Stephens and Winkler 1995: 79-245.

${ }^{8}$ Stramaglia 1999: 40 referred to them among the seven possible aspects of ghosts.
} 
seems to correspond to the final years of the first century AD. In the plot of the aforementioned novel, two compositional main ideas are combined, one that belongs to the novels and, on the other hand, the scheme of the fictional journey, that includes plentiful paradoxographical material. Likewise, the structure of a "Chinese box" is characteristic of this novel, that is, the usual embedding of a story inside another. The abstract by Photius presents a large biographical frame of the main character, Dinias, to whom another narrator, Dercyllis, relates her story in turn. Photius expresses it in this way:

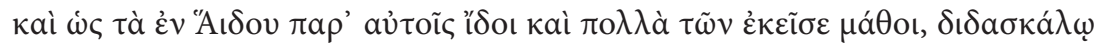

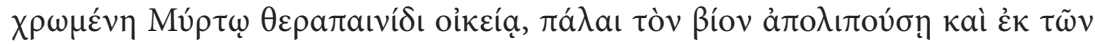

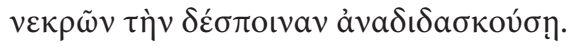

... and how she saw Hades' world among them (the Cimmerians) and she learnt many of the things from there, using her maidservant Myrto as her teacher, who died some time ago and instructed her mistress from the dead ones (109a 39 - 109b 2).

Luckily, a papyrus of this novel from the 2 nd century $\mathrm{AD}$ is related to this same episode, and says the following:

\section{PSI 1177:}

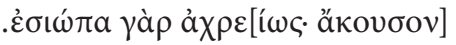

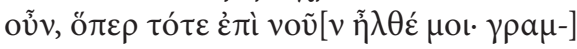

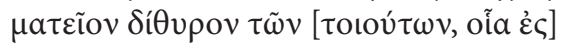

$\delta เ \delta \alpha \sigma \kappa a ́ \lambda o v ~ \varepsilon ̇ \pi \varepsilon \varphi \varepsilon \rho o ́ \mu \varepsilon \theta \alpha, \grave{\alpha} \pi[\circ \lambda \alpha \beta \circ \tilde{\sigma} \sigma \alpha]$

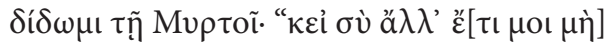

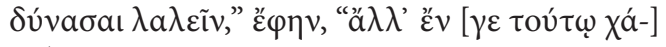

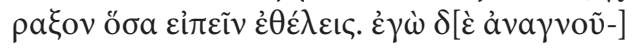

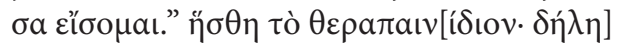

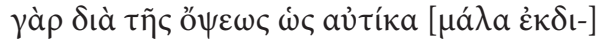

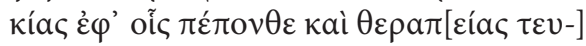

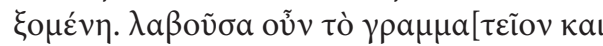

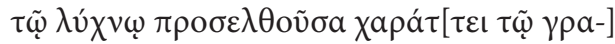

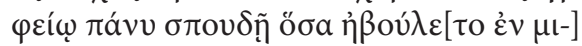

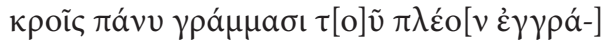

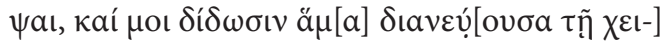

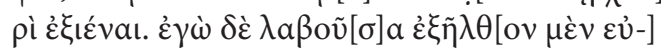

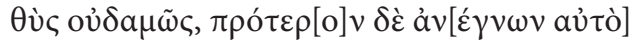

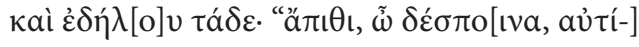

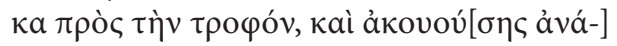

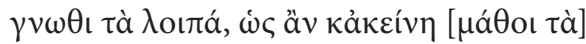

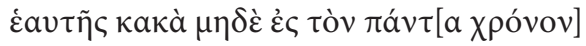

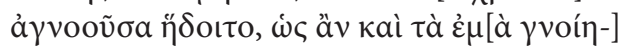




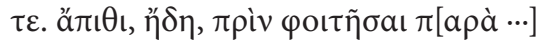

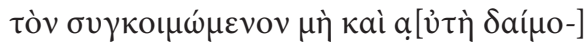

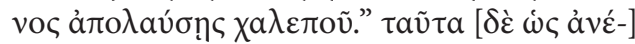

$\gamma \nu \omega v, \dot{\varepsilon} \beta o v \lambda o ́ \mu \eta \nu \mu \grave{\varepsilon} v \dot{\varepsilon} \pi \iota \sigma \kappa[\cdots \cdots . .$.

...she, indeed, kept silent pointlessly. So, listen what came to my mind in that moment: taking a small tablet of two sheets from those we carried to school, I gave it to Myrto. "If you cannot tell me anything more" - I said to her- "at least write here whatever you want to tell me. When I have read it, I will know it". My maidservant was pleased, as it was evident by her face that she wanted to get revenge immediately and recover from what she had suffered. So, she seized the small tablet and, bringing it closer to the light, she wrote with the punch in a great hurry whatever she wanted in small letters because there would be more room for more letters, and she gave it to me at the same time as she gestures to me with her hand to go. But, grabbing it, I went in no way immediately, but I read it first, and it said the following: "Go immediately, mistress, beside your nurse, and when she could hear it, read the rest, so she will find out her own misfortunes too and she will not be happy in her ignorance in the future, and you will also know mine. Go now, before I come together with... he who lies with me, so you can also enjoy a cruel ghost". When I read these things, I wanted...

It is interesting to highlight that this novel includes a first-person oral narrative of Dercyllis, where it is insinuated in this narrative written by a ghost, (apparently in Hades) the presence of another possible ghost ${ }^{9}$. The narrator/ author of the written narrative is now the maidservant of the main character, Myrto, to whom a villain, the Egyptian magus Paapis, has left mute as a result of a spell, according to Photius. It seems that he has also casted a spell on Dercyllis' nurse, among other misdeeds against the protagonist's family, which are significant misdeeds to the plot (as we infer from Photius' abstract). Here we see the erotic motif joined to the ghost one. The word daimonos (28-29), which is the most probable reading, appears to be interpreted as "spirit" or "ghost" in this context, although, joined to the adjective khalepós, its meaning

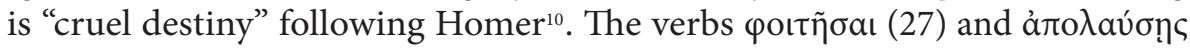
(29) frequently have erotic connotations, according to the Liddell-ScottJones' lexicon. These undertones very well may be applicable here. Thus, the sexual threatening will also be spread to Dercyllis, who is the oral narrator of the story that her maidservant has made her to read. On the other hand, the nurse and the family that are noted in this novel are typical of the New Comedy, and maybe of the Middle Comedy too. We might add that the motif

\footnotetext{
${ }^{9}$ For the study of the fragment see Stephens and Winkler 1995: 150-153.

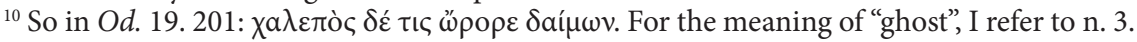


of the young man (neanías) that guides the narrator to Hades appears in Luc., Philops. 25. $10^{11}$.

5. A family intrigue is noted as well in another papyrus, dated back to the middle of the second century $\mathrm{AD}$, in which a magus talks to the parents of a girl who is visited by a ghost and, after describing all his powers, he recognizes that the only thing he cannot take under his control is love. Next the magus says the following:

P.Mich. inv. 5. 18-23

.....

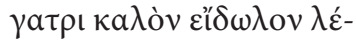

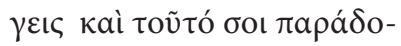

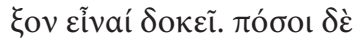

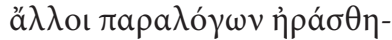

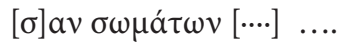

You say that a handsome image is appearing to your daughter and it seems to you that it is a wonderful thing. But, how many others have fallen in love with extraordinary creatures...?

We cannot say for sure that this "handsome image" (kalon eidōlon) corresponds to a real ghost. In the Phasma by Menander, referred above, a young man is also in love with a supposed ghost of a beautiful girl. But it could be a similar case to the well-known story that Phlegon of Tralles, Book of Marvels 1, narrates about the young Philinnion, dead shortly after her wedding, who returns to life and has sex with Machates, a guest of her parents ${ }^{12}$. Here the ghost, or revenant, of the girl is called by the terms anthropos (1;3), opsis, (11), theama (12), and phasma (18). In any case, the rhetorical level of the text is very high, and it should be noticed that these words are said through a magus, who enumerates all his powers, but he recognizes that he does not have a remedy against love, and in turn he asks for a remedy for himself, if it exists (15-18). It is another example of magus in love, as the magus referred by Antonius Diogenes in the previous papyrus seems to be ${ }^{13}$. It is interesting to compare these magi with the Hiperborean magus mentioned by Luc., Philops. 13-14, where his powers are described as: to send love, to rise ghosts, to make rotten corpses return to

${ }^{11}$ Ogden 2007: 183ff comments on it. Of course the oldest source is the Nekyia, in Odyssey 11 , which we mentioned above.

12 The story, in which a nurse is also present, is inserted in a letter sent by the governor of Amphipolis to a character close to Philip II, according to Proclus (5th century AD). The text is translated and commented by Stramaglia 1999: 223-253, Ogden 2002: 159-161.

${ }^{13}$ Stephens and Winkler 1995: 178 consider other possibilities for this apparition, not only the ghostly one. See the long commentary by Stramaglia 1999: 258-265. There is no proof that this fragment belongs to Antonius Diogenes' novel as well, as it was thought in previous studies. 


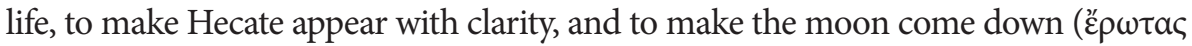

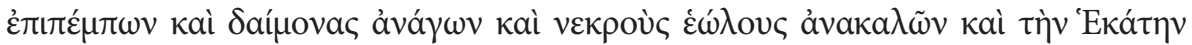

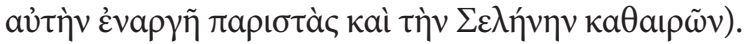

We can add that Ach. Tat. 2.25 puts in the mouth of the heroine the mention

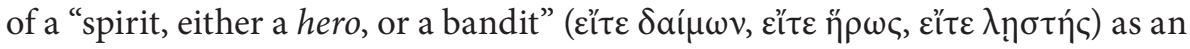
excuse to justify the visit of a possible nocturnal lover in front of her mother: we will find these three types of possible ghosts in other texts. Achilles has read many tales of ghosts.

6. The motif of the ghost who speaks about another ghost in a first-person narrative appears in papyrus fragments from the second half of the second century $\mathrm{AD}$, that seem to correspond to a comic novel, and its content reminds one of the tales that the main characters of Lucian's Lover of Lies relate. Let us see the text:

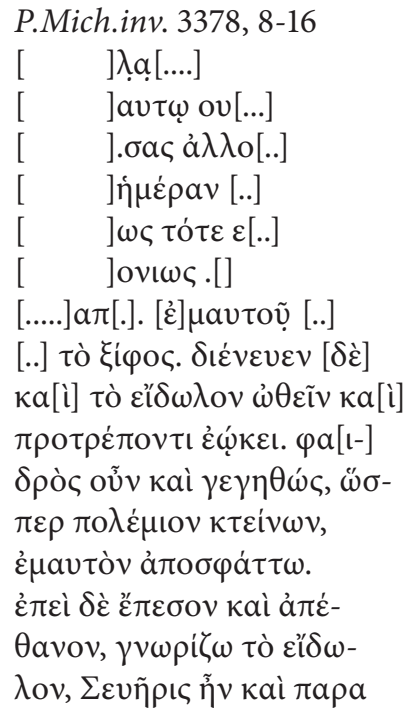

... the sword. The spectre also gestured to me to stick it into myself, and seemed to be encouraging me to do so. Accordingly then, cheerfully and contented, as if I were proceeding to slay an enemy, I cut my own throat. When I fell to the ground and I died, I recognized the spectre: it was Severis and close to...

In this case, the story could correspond to an inserted narrative or a second-level narrative. In spite of its brevity, the text presents itself in a highly stylistic level ${ }^{14}$. It should be highlighted that the verb used to "gesture" (dieneuen, 8) matches the one we have read in PSI 1177, 19, relating to Antonius Diogenes.

${ }^{14}$ This is something noted by Stephens and Winkler 1995: 428 and Stramaglia 1999: 95 and 152 n. 12, where our text is compared with Plin., Ep. 7. 27. 5-11. 
7. The next two texts we will quote belong to Lollianus' Phoenicia, a novel dated in the second century $\mathrm{AD}$, and of which some papyri remain ${ }^{15}$. One contains some scenes of sexual orgies, an apparent ritual of canibalism and every type of bizarre behaviours practiced by some bandits. Let us take a look at the relevant papyrus, which has been dated towards the end of the second century $\mathrm{AD}^{16}$ :

7.1. PColon.inv. 3328, B.1 verso, 21-30:

.oi $\mu] \dot{\varepsilon} v \kappa a \theta \varepsilon \tilde{\delta} \delta o v$ ảं $\alpha \gamma o \rho \varepsilon v ́-$

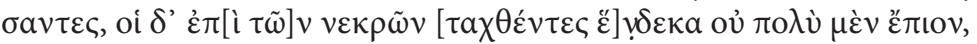

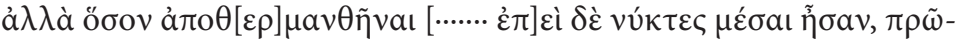

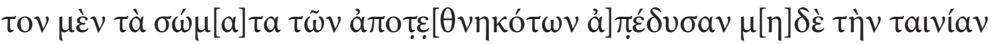

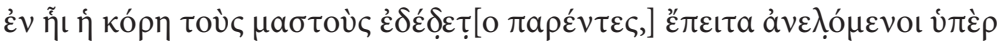

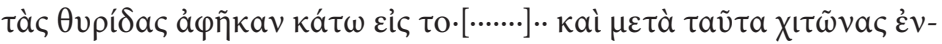

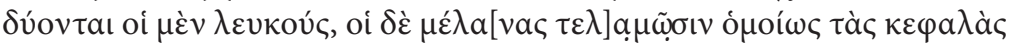

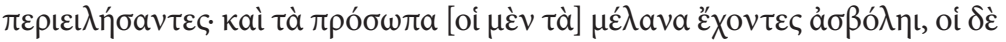

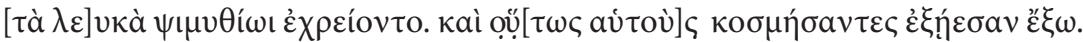

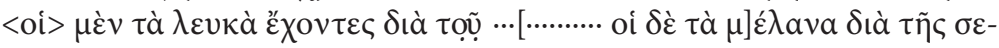

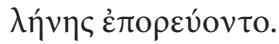

some of them slept exhausted, but the eleven that were [in charge] of the corpses, did not drink very much, but only what was necessary to get warm […... Wh] en it was midnight, in first place, they disrobed the bodies of the dead, not even leaving the ribbon with which the young girl bound her breasts; then, lifting them as far as the window, they threw them downwards, towards the $\cdot[\cdot \ldots . . . \cdot] \cdot \cdot$ and after this, they got dressed in tunics, some white, others black, and likewise they covered their heads with bandages; and the ones who wore the black tunics painted their faces with soot, and those with the white, with white lead. And after making up in this way, they went out. The ones who wore the white walked under the ………... those who wore the] black, under the moon.

We know that the main characters are bandits. Obviously, this is another case of false ghosts that want to scare the village. The motif can be compared with the one narrated by Lucian, Lover of Lies 32, where Democritus writes that

${ }^{15}$ See the study by Winkler 1980, and the edition and commentary by López Martínez 1998: 183-185, and Stephens and Winkler 1995: 342ff.

${ }^{16}$ The editio princeps is still useful with a very valuable commentary by Henrichs 1972: 96 and $122 \mathrm{ff}$. We have followed his translation in the less clear passages. I wonder if the previous scene to the mutilation of the bodies by the bandits might be served as an example of the maschalismós mentioned by Ogden 2002: 162 to other texts in which it is tried to avoid the revenge of the dead with their mutilation. These bodies could be considered as possible ghosts, and this belief can be seen underlying some of the examples presented here. 
some young (neaniskoi) wearing black dresses and masks want to scare him. Apuleius, Met. 4. 22, tells a story of some thieves dressed up as ghosts ("the thieves, ones armed with swords, others dressed up as ghosts -lemures- moved away quickly"), which indicates that the audience enjoyed the topic, which is frequent in the contemporary narrative.

Another papyrus belonging to the same novel is preserved, also from the end of the second century $\mathrm{AD}$, relating to the apparition of a new ghost:

\begin{tabular}{|c|}
\hline 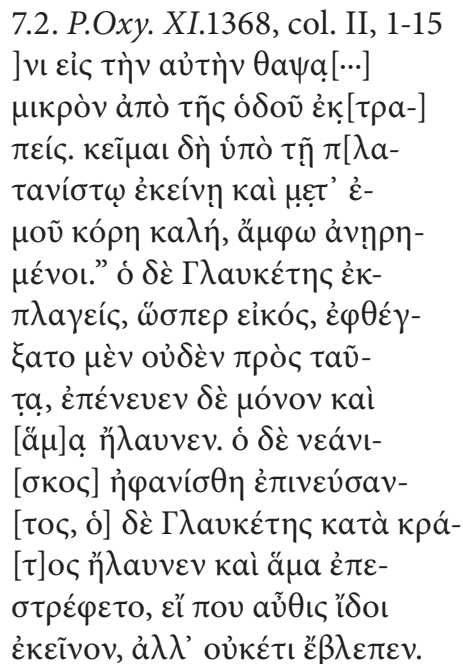 \\
\hline
\end{tabular}

...getting away from the path just a bit, bury us... in the same (grave?)... I lie under that plane tree, and with me a beautiful girl, both of us murdered". Glaucetes, astonished, as one would expect, did not answer, but just nodded his head as he spurred his horse on. The young man disappeared as Glaucetes nodded to him. Glaucetes urged on his horse hard, and at the same time turned his head, just in case he might see him again in some way, but he could not see him anymore.

In this case it seems to be a ghost that reports the crime perpetrated against him and a beautiful girl with whom he would have a love story, so he can be an example of ataphos, the dead deprived of burial, which we have pointed out among the categories referred by Ogden ${ }^{17}$. Here a certain Glaucetes is the one who is left speechless because of the scare, only able to nod in agreement. The ghost also gestures, as in previous occasions, but this time by means of the verbal

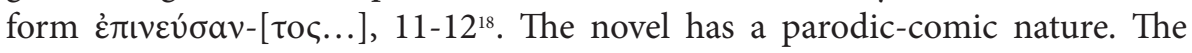

\footnotetext{
${ }^{17}$ Supra n. 2.

${ }^{18}$ In the scene of necromancy in Heliodorus, Aethiopica 6. 14. 6, a corpse appears uttering
} 
motif of the ghost that returns to inform him that he has been murdered is also present in Apul. Met. 8. 7. 4, in the story of disconsolate Charite, who honours the imagines of her dead husband every night, while presenting him as Bacchus.

\section{Conclusions}

In three of the nine texts studied, ghost stories are narrated in the first person: they are the texts numbered 1, 4 and 6. The texts quoted in 1,2, 3.1 and 7.1 present a fake ghost for sure. And it is possible that the narratives grouped in numbers 4 and 5 also have the same character. That is, most of our ghosts have false deaths or fake deaths. The ghosts of the texts numbered 4 and 7.2 could be real ghosts, and this is also possible in text number 5 . In the numbers 4, 6, 7.1 and 7.2 we have comic novels or comic-parodic novels, that emphasise in this way the fictional and paradoxographical character of their plot. Ghosts that speak about other ghosts appear in numbers 4 and 6 . Numbers 1 and 6 deal with ghosts of recently dead, while number 7.2 is about an ataphos. The ghost of the text number 6 speaks to report his own death. And we do not know to what extent it is the same in the text number 4 .

To name the ghost the following substantives are used: anthrōpos (1), eidōlon (3.1, 5, and 6), daimōn (2 and 4), neani-(scos) (7.2) and phasma (3.2). We have seen that these designations are similar to the ones that appear in the contemporary literature. This text by Lucian, Philops. 29. 16-20, is especially interesting on that subject:

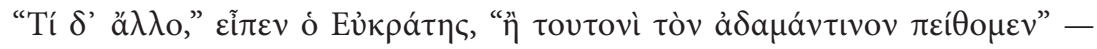

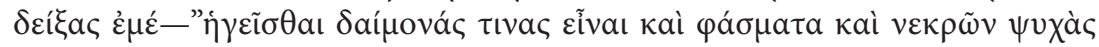

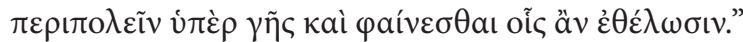

"What else, Eucrates said, except that we are trying to persuade this man of adamantine (pointing to me) to believe that spirits and ghosts exist, and that the souls of the dead go for a stroll in the living world and they appear whoever they want?"

Lucian is denouncing the credulity of his time in such apparitions, and he introduces the rich, cultured people of the Empire, that is, the pepaideumenoi.

no words, only making signs. This time Heliodorus also employs the participle of this verb, epineusas, and later the infinitive without preposition, neuein (6. 15. 2). For more on this scene and the magic in Greek novels see Ruiz-Montero 2007. Also see the story narrated by Apul. Met. 2. 28-29 and the notes of Ogden 2002: 136-140. For more on the referred papyrus see also the commentaries by López Martínez 1998: 190-196, Stephens and Winkler 1995: 325-327, Stramaglia 1999: 332-337, who thinks that this scene can belong to the main plot, and Henrichs 2010: 76-77. 
That public is the addresses of his True stories, according to his own words (preface, 1-2). And such fictional and learned novel as Antonius Diogenes' The incredible things beyond Thule is dedicated by the author to his learned (polymathes) sister Isidora and to a certain Faustinus whose personality is not clear ${ }^{19}$.

In Imperial literature the term preferred to designate the ghost, according to the data of TLG, is phasma, reaching its larger number of uses in the second century AD. Plutarch is the Greek author that exhibits more of these occurrences. The novel, the same as in papyri and contemporary literature, distinguishes between two types of daimon: the good and the evil, although such characteristic is not always clear in our fragmented texts. These are ghosts that confine themselves to scaring, as the bandits of the text number 7.1. But there can be beautiful ghosts too, as the one in the text number $5^{20}$.

The appearance of the ghosts is described in texts number 1.2, 3.1 and 7.121. Let us add the descriptions which Lucian and Pausanias provide. Lucian's Lover of Lies presents some examples, the first of them corresponding to a possessed ${ }^{22}$ :

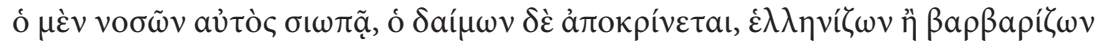

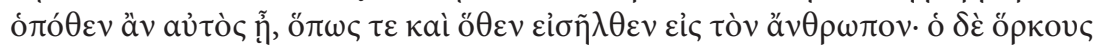

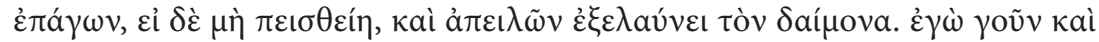

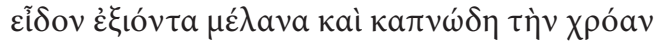

The ill person himself keeps silent, but the spirit answers, either in Greek language or in a foreign one, depending on its origin, how he has possessed that person; he, uttering oaths just in case he does not obey and threating, wards off the ghost. Indeed, I also saw the ghost leaving, his skin being black and burnt (16. 12-17).

In other case we read the story of the house uninhabited because of fear to

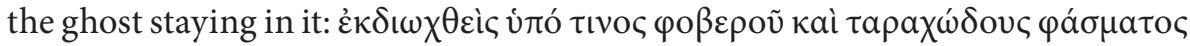
("haunted by a certain horrible and terrifying ghost", Luc. Philops. 31. 4-5). In this case the ghost was the inhabitant of the house. The end of the story goes as follows:

\footnotetext{
${ }^{19}$ It could be the character sometimes referred to by Martial. Stephens and Winkler 1995: $101 \mathrm{ff}$ offer a good introduction to this novel.

${ }^{20}$ In Ach. Tat. 6. 4. 4 Leucippe's beauty is compared to the one of a beautiful ghost (phantas$\mathrm{ma}$ ) appearing in dreams.

${ }^{21}$ Stramaglia 1999: 36-40 distinguishes seven possible appearances of ghosts in literary and iconographic sources.

${ }^{22}$ For this and the rest of the narratives from the mentioned work by Lucian, I refer to the study by Ogden 2007: 131-136, which gives interesting intercultural parallels.
} 


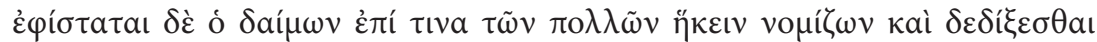

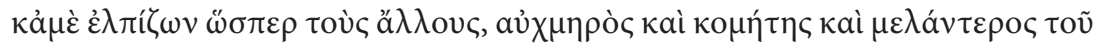

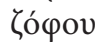

The spirit appears thinking that he went before a normal man, and being reckless I was also going to fill me with scare, as the others: disgusting, long hair, and darker than darkness (31. 16-19).

Pausanias presents the story of Hero, a ghost dead by the hand of Euthymos in Elide, among his stories:

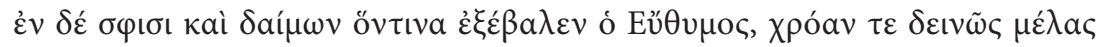

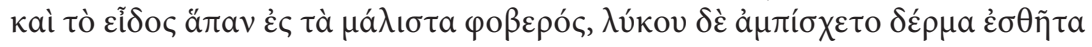

In these places there was also a spirit of whom Euthymos succeeded to ward off: the colour of his skin was terribly dark, and all his appearance was awful, and he was covered with a wolf skin (6.6.11).

We have seen that contemporary Latin narrative offers parallels to these narratives, and we have quoted some examples from Apuleius' Metamorphosis. We add Met. 9. 29-33 to them, where it is told the story of a wife who looks for a witch that can introduce into the house some spectre (larva) or some dreadful divinity (divo numine) in order to make her husband die with violent death ${ }^{23}$. The crime will be committed by the ghost (umbra) of a woman who has been condemned to a violent death. Her appearance is described as deathly pale, her face is disfigured, she is barefoot and horribly thin, and her hair is messy, dirty and whitish, and with a layer of ash hanging down over her face, and it covers the largest part of her face (discerptae comae semicanae sordentes inspersu cineris pleramque eius anteuentulae contegebant faciem).

The adjective aukhmeros, which we have mentioned in previous texts, seems to be a topos to make reference to the awful appearance of a ghost, or to his hair, especially messy and dirty, and in fact the ghost of Hector also appears to Andromacha "covered by a messy hair" (squalida obtectus coma) in Sen. Tro. $450^{24}$. In the same way, it is worthy to emphasise the assimilation between the physical descriptions of the ghost and the bandit in this type of fictional literature. Thus, in Ephes. 1. 13. 2 we read the description of a commander of pirates, which follows a pattern very similar to the ones of the aforesaid ghosts: veavíaৎ ỏ $\varphi \theta \tilde{\eta} v a$ ।

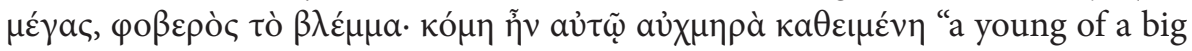

\footnotetext{
${ }^{23}$ See the useful commentaries by Hijmans Jr. et al. 1995, and Ogden 2002: 152-154.

${ }^{24}$ Other texts are Sen. Oed. 608: squalidam obtentus comam; Med. 740: squalidae Mortis specus.
} 
size, horrible glance; his long hair was hanging down messy"25. It seems to be a rhetorical cliché.

Let us finish reminding that among the progymnasmata, particularly in the treatment of the ethopoiía or prosopopoiía, it exists the called eidolopoiía, the creation of a discourse spoken by a spectre; there are examples of the eidolopoḯa in Hermogenes and Aphthonius, as Stramaglia emphasises, and some papyri of them remain ${ }^{26}$. The circulation of these stories are double, oral and written, and when we say "oral", we refer not only to the way of transmission of these fictional narratives, but to the fact that their enunciation are usually framed in an oral context, both in the here analysed novels and in Lucian. His play Lover of Lies, referred to many times in this chapter, it is one and the same as the genre which we have studied ${ }^{27}$. It is evident to conclude that the repetitions appearing in its narrative patterns confirm this is a well-typified genre in the rhetoric schools. The fact that there was also a pedagogic utility is evident from texts such as Plut., Aud.poet. 1. 14E, in which it is mentioned the pleasure of the young students in the reading of texts that have to do with the "doctrines about the soul mixed with the fictional narratives"28.

Regarding to the currency and the trendiness of the topic, I quote two texts: I read the first one in the epitaph of the poet Miguel Hernández in the cemetery in Alicante: "Aunque mi amante cuerpo bajo la tierra esté / escríbeme a la tierra, y yo te escribiré" ("Although my loving body would be under the ground / write to me to the ground, and I shall write to you"). The second one is a fairly recent film, Ghost, absolutely real and well-documented, according to the experts on the subject, because haberlos, haylos ("that there are ghosts, there are"). They are as important in the classic world as in our own days, because they are inseparable from the human being, as they are both life and death, which is the step to "another life".

${ }^{25}$ More information in Stramaglia 1999: 41. It should be also noted the expression $\dot{\varepsilon} \mu \varphi a v i ́ \zeta \omega v$

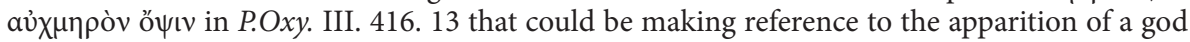
in dreams; about its possible fictional character see López Martínez 1998: 347-352 and Stephens and Winkler 1995: 409. Menelaus applies this adjective to the awful appearance of Orestes,

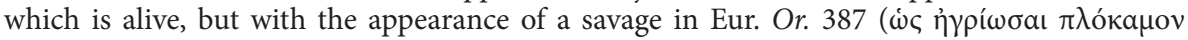

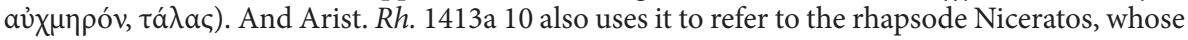

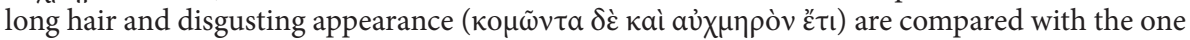
of the Trojan hero Philoctetes. Pl., Symp. 203d uses the adjective to refer to the appearance of Eros as contrary to "beautiful" (kalós).

${ }^{26}$ Stramaglia 1999: 87-91 refers appropriately to Cribiore 1996.

${ }^{27}$ See my forthcoming article "Oral tales and Greek fictional narrative in Roman imperial prose", and Stramaglia 1999: 82-87.

${ }^{28}$ Stramaglia 1999: 90. 